\title{
На фоне Центральной Европы: Преимущественно вежливый Леопольд в сети мужских персонажей романов Михала Вивега
}

https://doi.org/10.34739/clit.2021.15.19

\section{At the Background of Central Europe: Mostly Respectful Leopold in the Net of Male Characters of Michal Viewegh's Novels}

\begin{abstract}
The author of the present study investigates the character of Leopold in the new novel by Michal Viewegh in the net of the characters of his preceding novels. In this novel, the writer does not discuss politics, the problem of men and women, husbands and wives, and the sexual promiscuity, but, above all, unstoppable aging and permanent support of the gradually waning sexuality. Leopold is a metaphor of anatomy and physiology of a Central European man who, in his own manner, has always aimed at searching new ways, at the beginning of new epochs, at the anticipation of new ideas and at the formation of new humans under the changed conditions. Viewegh - already in his quasipostmodernist poetics, and due to his extreme opinions and language and style inventions - belongs, covertly or openly, to the mighty stream of unclear, vague, ambivalent Central European literature.
\end{abstract}

Keywords: new human, the hero's aging, homo Europae centralis, quasipostmodernism, ambivalence, vagueness

Итальянский германист Клаудио Магрис в своей книге Дунай (Danubio), написанной накануне большого переворота конца 80-х годов $\mathrm{XX}$ века, подчеркивает именно культурное значение упомянутой реки как связующего звена Центральной Европы. Дунай объединял немцев, западных славян, венгров, южных славян, касался и территории восточных славян, связывал территорию Центральной Европы с Балканами и медитерранным ареалом. В книге Центральная Европа 
u славяне 1 я пытался показать некоторые личности, которые можно с определенной долей гиперболы назвать homo Europae centralis, т.е. если существует человек балканский (homo balkanicus), можно говорить и о человеке Центральной Европы, который владеет активно и/или пассивно несколькими языками этого культурного ареала, читает разные национальные литературы, способен вчувствоваться в менталитет своей нации, но и других наций и этнических групп. Таких людей теперь сравнительно мало, было их, наверное, больше, так как культурный ареал Центральной Европы потерял многое из своего прежнего значения в силу разных исторических событий XX века, именно Первой мировой войны и распада Австро-Венгрии, Второй мировой войны и последующей холодной войны и т.д. В наших многочисленных статьях, которые касались Центральной Европы и ее широкой проблематики, мы упоминали и характерные черты ареала и его территориальные связи. На тексты этих исследований мы и здесь, во вводных частях настоящей статьи, ссылаемся².

\footnotetext{
${ }^{1}$ I. Pospíšil, Střední Evropa a Slované (Problémy a osobnosti), Brno 2006.

2 Здесь приводятся лишь избранные; не упоминается редактирование многочисленных конференционных сборников, коллективных монографий и пр. I. Pospíšil, Рождение среднеевропейской поэтики (Ф. Каутман - О Филип - Й. Зогата - М. Вивег), [в:] Взаимодействие литератур в мировом литературном процессе. Проблемы теоретической и исторической поэтики. Материалы X международной научной конференции в двух частях. Часть 1, ред. Т.Е. Автухович, Гродно 2005, с. 79-91; I. Pospísil, Il centrismo interletterario mediterraneo e la letteratura russa, [в:] Il Mediterraneo. Una rete interletteraria. La Méditerranée. Un réseau interlittéraire. Stredomorie medziliterárna siet', a cura di D. Ďurišin, A. Gnisci, Roma 2000, c. 101-109; I. Pospíšil, El centrismo interliterario mediterráneo y la literatura russa, [в:] Literatura europea comparada, Compilación de textos C. Domínguez, Madrid 2013, c. 313-322; I. Pospíšil, Средняя Европа как перекресток литературоведческой методологии, [в:] Взаимодействие литератур в мировом литературном процессе (Проблемы теоретической и исторической поэтики). Материалы международной научной конференции, часть 1, отв. ред. Т.Е. Автухович, Гродно 1997, c. 3-10; I. Pospíšil, M. Zelenka, René Wellek and Interwar Czechoslovakia: the Roots of Structural Aesthetics, [in:] BUNMEI (Civilisation) 17, Tokyo 1998, c. 79-89; I. Pospíšil, M. Zelenka, Střední Evropa jako křž̌ovatka metodologií: Slovesnost Slovanů Franka Wollmana - tradice a souvislosti (Nad druhým českým vydáním), [в:] F. Wollman, Slovesnost Slovanů, eds. I. Pospíšil, M. Zelenka, Brno 2012, c. 23-68, I. Pospíšil, Problémy terminologie a střední Evropa, [в:] Brněnská hungaroslavistika a česko-slovensko-mad’arské vztahy, eds. I. Käfer, I. Pospíšil, E. Sztakovicsová, Szeged 2012, c. 45-57; I. Pospíśil, Střední Evropa: posuny dưrazu, [v:] Střední Evropa včera a dnes: proměny koncepcí. Kolektivní monografie, ed. I. Pospíšil, Brno 2015, c. 9-20; I. Pospíšil, Central Europe: Substance and Concepts, Nitra 2015; I. Pospísil, Методология и теория литературоведческой славистики и Центральная Европа, Siedlce 2015; I. Pospíšil, Проблематика сущности и развития русской литературы с точки зрения Цетральной Европь, [в:] W kręgu języka, literatury i nauczania, ред. Л. Павера, BielskoBiała 2017, с. 215-232; I. Pospíšil, Россия и Центральная Европа с особым учетом чешско-
} 
Вместе с развитием особой культурной, духовной атмосферы на территории Центральной Европы образовалась и особая литература, связанная с ее судьбами, насыщенная специфическими приемами, темами, мотивами, персонажами и проблемами. Именно особая культурная атмосфера центра Европы способствовала формированию личностей, особо чувствительных к разным менталитетам и манифестациям мультинациональных и мультикультурных начал. Однако этот ареал не был сложным только с ментальной и культурной точек зрения; огромные политические сдвиги XX века повлекли за собой испытания характеров и трагедии человеческих судеб. Общественные катаклизмы и последствия революционных переворотов воздействовали на ареал прежде всего в межвоенный и послевоенный периоды.

В нашей книге о Центральной Европе и славянах приводится несколько примеров таких личностей. Среди них, между прочим, Франтишек Каутман (1927-2015), журналист, редактор издательства, литературовед и литературный критик, издатель, поэт, переводчик и прозаик, деятель культуры, который подписал известный документ чехословацкого диссидента Хартия 77, член Dostoyevsky Society, член Общества Ф.Кс. Шальды, основатель и секретарь Клуба освобожденного самиздата. Доминантной чертой его художественных и философских размышлений являются экзистенциальные проблемы человека под давлением истории, одиночество и тревога.

Есть литературные произведения, которые имеют большое значение не потому, что радикально развивают поэтологическую систему литературы, а скорее потому, что они движутся на грани литературных жанров, что они в этом смысле слова экспериментируют, гениально отражая более широкие контексты, становясь, таким образом, эмблемой определенного пространства и времени. Таким можно считать изданный в 2000 году одновременно по-немецки и почешски роман прозаика, переводчика и журналиста Оты Филипа (1930-2018) Седъмое жизнеописание. Этому произведению я уделял

русских литературных связей, [в:] Универсалии русской литературы 2, сборник статей, ред. А.А. Фаустов, Воронеж 2010, с. 606-628; I. Pospísil: Ареальные исследования: между Центральной Европой и Россией, [в:] Kultura rosyjska w ojczyźnie $i$ diasporze. Księga jubileuszowa dedykowana profesorowi Lucjanowi Suchankowi, red. L. Liburska, Kraków 2007, c. 49-57. 
в некоторых своих статьях особое вниманиез 3 Сегодняшний обзор можно, следовательно, понимать как новое звено в этой цепи и как резюме данной проблематики; кроме поэтологической, т. е. Морфологической точки зрения, и позиции визуализации и присутствия юмора, результатом которого является гримаса, тягостность, грусть и тревога, или же с точки зрения сравнительного аспекта 4 , кажется, что важной проблемой является среднеевропейское геополитическое пространство.

Чешский писатель Михал Вивег (Michal Viewegh, рожд. 1962), издал в течение нескольких лет сравнительно много произведений, которые можно обозначить словом роман или повесть 5 . Их основной чертой является присутствие метатекста и интертекста, игры с чужими текстами, пародии и травестии литературных жанров и - в противоположность традиционной фальшивой чешской скромности - значительной степени эксгибиционизма, который выявляется в многочисленных интервью, где писатель пропагандирует свое творчество, образуя его массмедиальный фон.

Творчество М. Вивега образует один полюс наиболее популярной чешской литературы на грани двух тысячелетий - это на публицистике и массмедиальной тривиальной основе построенная литература, которая формируется по образцу моды легко пародируемых общественных и языково-культурных элит, воспринимаемых квазикритически.

В центре его романных произведений стоят обычно мужские герои. История частного детектива Дениса Правды и писателя Норберта

\footnotetext{
3 I. Pospíšil, Humor jako mobilizace psychiky, potencialita, zmarňování, přesah a nebezpečí (Sedmý životopis Oty Filipa a jeho předchůdci), „Stylistyka” 2001, nr X, c. 33-46; I. Pospíšil, Osobnost a literární žánr v kleštích dějin (Poetika dějinného zmarňování na pomezí faktu a fikce aneb Ahasver 20. století: román Oty Filipa Sedmý životopis, „Slavia Occidentalis“ 2001, t. 58, c. 58-155, I. Pospíšil, Mitteleuropäische Dimension und mitteleuropäisches Schicksal in Ota Filips konfessionelem Roman-Dokument Sedmý životopis, [в:] Litteraria Humanitas XI. Crossroads of Cultures: Central Europe, ed. I. Pospíšil, Brno 2002, c. 305-316; I. Pospíšil, Vizualizace $v$ komplexu uměleckých detailu v románu Oty Filipa Sedmý životopis, [в:] Dwudziestowieczna ikonosfera $w$ literaturach europejskich. Wizualizacja $w$ literaturze, red. B. Tokarz, Katowice 2002, c. 299-307; I. Pospíšil, Literatura a úzkost: Ota Filip a Oksana Zabužko, „Bohemica Litteraria” 2001, V 4, c. 147-153.

5 Názory na vraždu (1990), Báječná léta pro psa (1992), Nápady laskavého čtenáře (1993), Výchova dívekv Čechách (1994), Účastníci zájezdu (1996), Zapisovatelé otcovský lásky (1998), Povídky o manželstuí a sexu (1999), Nové nápady laskavého čtenáře (2000), Román pro ženy (2001), Báječná léta s Klausem (2002), Vybíjená (2004), Lekce tươč́ího psaní (2005), Román pro muže (2008), Biomanželka (2010), Mafie v Praze (2011), Biomanžel (2015), Zpátky ve hře (2015), Bůh v renaultu (2017), Převážně zdvořilý Leopold (2020). Его произведения были переведены на 21 язык, включая польский и русский.
} 
Черного происходит в мнимо фиктивной среде; по ряду внешних и внутренних автобиографических данных ясно, что это современная Чехия и чешское общество начала XXI века. Демонический характер творчества М. Вивега в целом напоминает моделирование мира М. Кундеры в его цикле повестей Смешные любови. Вивег детерминирует свой сюжет в форме исходной ситуации, предвосхитившей развитие действия: писатель подвергает допросу детектива и принуждает его рассказывать историю слежки за его любовницей Кларой. В то время как модернисты формировали свое искусство как способность видеть мир будто бы в первый раз (формалистическое «остранение»), М. Вивег, исходивший из постмодернистской поэтики, строит свой рассказ на автоматизации; его люди - чтобы избежать постмодернистской амбивалентности и тотальной неуверенности - хотят предотвратить их. Аутентичные манифестации человеческого эго, как, например, ревности, фактически доминантной темы романа, устраняются путем автоматизации: детектив Правда и его жена Рут говорят о физиологических деталях своих любовных приключений ${ }^{6}$

В одном из романов (Vybíjená, 2004, по-русски Вышибалы), автор вернулся к традиционной дезинтегрированной романной модели c разными точками зрения (джеймсовскими points of view). Никакой мир an sich не существует, есть только миры нарративов, изолированные целые, не имеющие ничего общего или встречающиеся лишь иногда. Есть только здесь и теперь, ценности умирают как эфемериды только в час своей массмедиальной презентации.

Вивег превосходно владеет методом коллажа - постмодернизм для него только часть торта, приготовленного собачкой и кошкой?: начиная с обсессивных намеков на Клауса и заканчивая ностальгией, грустью безысходности и новым включением в ежедневный автоматизм - его новый человек столь искренен, что его искренность становится несносной, выражая лишь новый размер неискренности. Прозвища вивеговских персонажей напоминают воспоминания о фильмах и телепередачах их молодости.

Вивеговский „новый человек“ XXI века - это начитанный зверь, который воспринимает все как смерть, у него нет никаких оценочных иерархий, и свое образование он культивирует лишь для того, чтобы

${ }^{6}$ M. Viewegh, Př́ipad nevěrné Kláry, Brno 2003, c. 49-50. 
устранить из жизни напряжение, неуверенность и амбивалентность: неожиданные моменты можно элиминировать путем автоматизма. Наряду с демонизмом, моделирующим мир по своему образцу, и хроникальной текучестью Вивег находит третий путь, а именно способность идентифицировать свою жизнь с моментом истории, с годиецентризмом нового времени.

На поверхности проза Вивега как бы выявляет постмодернистскую амбивалентность, неуверенность, эксплуатацию схемы детектива, внутри она, однако, функционирует по-другому: в то время как у постмодернистов можно за этими передвижными кулисами найти глубокое раздумье, чувство суеты, искоренения и ностальгии, у Вивега это чувство травестировано. Главной темой Вивега является тема тотальной транспарентности: все живут как в аквариуме. Литература модернизма основала особую, но авторитетную оценочную экспериментальную структуру, постмодернизм исходил из плюрализма, из совокупности не встречающихся дискурсов, в квазипостмодернизме М. Вивега индивидуум полностью растворяется в глобализированном мире. Жизнь теряет свою цельность, пространство и время разделились на самостоятельные части, разбросанные гномы, изолированные крылатые выражения, эффектные слова, английские термины. В квазипостмодернизме искусство больше не способно спасти человеческую душу: его ценности не только амбивалентные, но почти нулевые, ограниченные моментом их возникновения и короткого существования. Квазипостмодернизм связан с деаксиологизацией современного мира, в котором смысл имеет лишь то, что существует в массмедиальной презентации: есть только короткое настоящее, никакого прошлого и будущего нет - это, кажется, выражение абсолютного недоверия к традиционной истории и политике. В то время как утопическая и антиутопическая/дистопическая литература проецирует все свои видения в будущее (футуроцентризм), которое или красиво, или угрожающе, традиционные дезиллюзивные прозы XIX века демонстрируют бессмысленность настоящего и будущего, обращаясь лишь к прошлому; постмодернизм паразитировал на падали чужих текстов, смешивая, таким образом, вполне естественно, настоящее и будущее; квазипостмодернизм живет только настоящим, сегодняшним днем. «Новый человек» прозаических произведений Михала Вивега начала $\mathrm{XX}$ века и квазипостмодернистский мир его маленьких романов 
и рассказов, кажется, предвосхищает некоторые черты мира в преддверии нового биг бенга (big bang), связанного и с внутренними изменениями человека.

С чем связано, однако, творчество Михала Вивега, так непохожее на приведенных авторов, выражающих более или менее традиции чешской литературы межвоенного периода, хотя они стали писать только после 1945 г.? Это, прежде всего, поиски нового человека на перекрестках наций, идей, вероисповеданий, образов жизни, менталитетов, которыми Центральная Европа реально или виртуально изобиловала и, частично, изобилует7.

Стареющий писатель, для которого все труднее сдержать обещание, что он напишет один роман в год, интересно выражает квазипостмодернистскую осцилляцию между неуверенностью и закрепленностью, например, в романе Уроки творческого писания (2005), который в рамках рекламы называется камерной психологической новеллой, что, кажется, является эвфемизмом для маленького романа. С течением времени романы Вивега становятся все короче, что маскируется большими буквами и особым набором. Вивег мастер уравновешенного отношения характера и среды: то, что было центром внимания в классическом реализме, в особенности на раннем этапе его развития, то, что типично для physiologie, т. е. Физиологического очерка, известного, между прочим, из русской натуральной школы 40-х гг. XIX века, но, в общем, для становления европейского реализма в целом. ${ }^{8}$ В данном случае это была среда, которую, как всегда, Вивег прекрасно знал, частный вуз, ныне уже бывшая Академия им. Йосефа Шкворецкого, среда достаточно конъюнктурная, чтобы в ней могли обнаруживаться проблемы чешской жизни рубежа XX-XXI веков и общечеловеческие процессы, концентрированные в маленьком

\footnotetext{
7 См. наши статьи о Вивеге: I. Pospíšil, Český kvázipostmoderní román: poetizace automatismu a zrození „nového člověka“ (Př́́pad nevěrné Kláry Michala Viewegha), [в:] Retoriki na pametta. Jubileen sbornik v čest na 6o-godišninata na profesor Ivan Pavlov, peд. B. Biolčev, V. Stefanov, K. Bachneva, P. Karagjozov, J. Bačvarov, Sofija 2005, c. 498-504; I. Pospíšil, Lekce tvưrčího psaní a kvázipostmodernistická poetika Michala Viewegha, „Stil“ 2005, nr 4, с. 303-313; I. Pospíšil, Quasipostmodernistyczny świat Michala Viewegha, [в:] Literatury stowiańskie po roku 1989. Nowe zjawiska, tendencje, perspektywy, Tom I, Transformacja, red. H. Janaszek-Ivaničkova, Warszawa 2005, c. 81-88; I. Pospíšil, Postmodernism and Quasipostmodernism (Michal Viewegh), „Neohelicon. Acta Comparationis Litterarum Universarum. Akadémiai Kiadó“ 2006, tomus XXXIII, fasciculus 2, Decemnber, c. 37-44.

${ }^{8}$ См. нашу статью: I. Pospíšil, Karel Krejčí, jeden sborník a úloha tzv. fyziologü, [в:] Karel Krejčí a evropské myšlení, eds. I. Pospíšil, M. Zelenka, Brno 2006, c. 39-47.
} 
пространстве одной семинарной группы студентов разного социального происхождения.

Вивеговский герой - это мужчина, суверен, молодой или скорее стареющий интеллектуал, сексуально промискуитетный писатель, в которого массого влюбляются девушки и зрелые женщины. В прологе к роману Вивег иронически упоминает свое обещание написать ежегодно один роман; начало мая 2004 года и автор со своим брненским издателем встречается на террасе кубинского ресторана на улице Капрова в центре Праги, недалеко Староместской площади, напротив теперь уже бывшего книжного магазина Фишер, где начинается автограмиада в связи с выходом в свет его романа Вышибалы. Автор обещает своему издателю новый роман о семинарной группе творческого письма: «-Mluvíme zrovna o mé př́íší knize, - Bude to př́iběh, který vznikne během jediného dne, v semináři tvưrčího psaní. Celé se to navíc odehraje přímo před zraky čtenáře. Prakticky z ničeho by před jeho očima

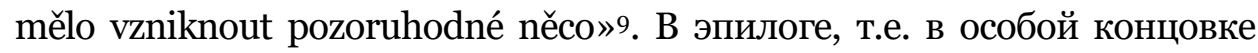
романа все подытоживается:

Sluneční odpoledne na počátku května 2005; autor a jeho nakladatel sedí na venkovní terase kubánské restaurace La Bodequita del Medio naproti knihkupectví Fišer, kde v pět hodin začíná autogramiáda autorovy nové knihy. - To sladké finále se mi líbilo, - ř́ká nakladatel. Řečeno s Oskarem Wildem, člověk by musel mít srdce ze železa, aby ho to nerozesmálo. - Záměrná nevěrohodnost -, poznamená autor ponuře. Vědomé použití kýče. Nám dvěma je to jasné. Ale oni to jako obvykle nepochopí. Respektive to nebudou chtít pochopit ${ }^{10}$.

Его автор-персонаж опять-таки успешный, неодолимый суверен, хотя здесь уже намечается подспудное течение ностальгии и утомительного повторения, тема банальности бытия, его автоматизма и схематичности. Модернизм, как известно, живет на падали старых текстов, поглащает их, используя их с другой целью и в другом контексте. Романы Вивега с их ностальгическими тематическими слоями, типичными для людей конца XX века, вырастают из корней сентименталистской поэтики, развиваясь как бидермейеровская картинка успокоенной жизни в качестве одного звена в цепи жанровых трансформаций, в рамках которых исходная жанровая основа

9 M. Viewegh, Lekce tviorčího psaní, Brno 2005, c. 9 (далее: Lekce).

${ }^{10}$ Lekce, c. 136. 
впитывает в себя новые тематические стимулы и связи без нарушения бидермейеровской поэтики: цепи повторений, стереотипов под давлением быстро меняющихся обстоятельств, что, разумеется, является фундаментом литературы в общем, ее ретардации, спасительного эффекта замедления, о котором бывало писал В. Шкловский в свой формалистский период.

В своих статьях о Вивеге я не раз называл его метод формирования постмодернистского романа и его стержневого авторагероя квазипостмодернизмом не случайно: между тем как модернисты считали искусство в общем как способность видеть мир будто бы в первый раз (остранение), экспериментировали и эстетической ценностью считали изобретательность и инновативность, постмодернисты конструировали свои произведения как интертекстуальные структуры, основанные на аллюзиях и на работе с чужими текстами и их амбивалентностью и ощущением неуверенности, аксиологической лабильностью, Вивег на своем квазипостмодернистском этапе хочет избежать постмодернистской амбивалентности, тотальной неуверенности и ценностной лабильности. Детектив Денис Правда и его жена Рут вверяют другу другу физиологические детали своих любовных авантюр:

A co Zdeněk, jaké to bylo?‘ Snadnost, s níž jsem dnes dokázal vyslovovat takovéhle otázky, mě ani po všech těch letech nepřestávala okouzlovat. Chceš to vyprávět? Doktor a zdravotní sestra? Takový klišé?‘, Ano.' Obvykle jsem rád znal podrobnosti - byl to jednoduchý a občas i docela vzrušující způsob, jak dostat Rút zase nazpět, jaksi nedotčenou, jestli mi rozumíte. Pokud mne totiž na jejích úletech vi̊bec něco popuzovalo, pak snad jen ona tupá domýšlivost některých jejích milenců. Normálně jsem mu tu jeho prsatou paničku přefiknul...Tím, že mi Rút pokaždé pravdivě převyprávěla veškeré detaily, se jejich domnělý triumf okamžitě změnil v nevědomou prohru. Žádné tajemství už neměli, byl jsem to naopak já, kdo věděl všechno: jaké nosí spodní prádlo, jak se v posteli chovají i jak si představují milostnou předehru. Nebylo to špatný, ale jako vždycky, když je to poprvý: kouzlo novýho versus nesehranost. ‘ ,Velký penis?' Před dvaceti lety bych při stejné otázce dostal infarkt; nyní jsem se klidně díval na kosatky. ,Jo. Tím pádem měl ovšem dojem, že se nemusí moc snažit.' Rút nikdy nepřidávala ani neubírala. Pravda nám dvěma už nemohla ublízit. ,Neudělala ses?‘ Nikdy si nenechte namluvit, že věcnost je vulgární. ,Ne.. Ale líbilo se mi to.‘ ,.To jsem rád.‘ Opravdu jsem byl rád. Položil jsem jí 
ruku do klína. ,Chceš to napravit?‘ Podívala se na mě trochu překvapeně. ,Jo.'Vsunul jsem dlaň do kalhotek a začal ji hladit ${ }^{11}$.

Автор структурирует свой роман графически путем использования курсива в обрамлении сюжета, в гномах, остротах, бонмо, шутках, в которых язык выступает в качестве оруэлловского ньюспика («ulice lidem!», «Fajn ňamka!», «mistře», «totální vojeb», «čmuchal», «Na cardy tohle bohatě stačì). Проблема состоит в том, что в чешском языке наличие разговорного чешского (mluvená čeština) или сленга, связанного с современными способами выражения, отражает не только отношение литературного персонажа к реальности, но и формирование псевдореальности, имманентной схемы, рефлектирующей и «конфекционность», отчужденность и бесконечную воспроизводительность типовой ситуации: реальность у Вивега образуется как нон-стоп копир, в котором понятие оригинала теряет свою ценность и смысл. Игра с героем или антигероем и своего рода непрестанные воспроизведения, вариации и модификации того же самого типа современного нового человека в поисках глубинного смысла существования путем все новых и новых авантюр и экспериментов, не без влияния ранних повестей Милана Кундеры.

Герой, воспринимающий прошлое через призму своей юности; потом становление нового человека и общественный успех и конъюнктура романов Вивега; потом кризис непрестанного повторения, жизненного автоматизма, из которого он хочет ускользнуть посредством постепенного экспериментирования и наглого, провокационного гедониума, что-то вроде вызова миру, как у Достоевского - все дозволено - в атмосфере чешских 90-х гг. XX века; потом наказание. Проблема мнимой долговечности романов Вивега состоит в том, что - несмотря на общие места - там слишком много конкретных намеков и аллюзий, связанных со временем и его реалиями, которые будут еще в близком будущем совсем непонятны читателю. В романе Вышибалы (2004) описывается известная причудливая псевдокоммуникация вечеринок абитуриентов, столкновения особых нарративных миров, их пересечение, протекание и исчезание.

${ }^{11}$ M. Viewegh, Př́ṕpad nevěrné Kláry, Brno 2003, c. 49-50. 
Ключевой проблемой нового человека Михала Вивега является его поза сплошной искренности, которая становится столь невыносимой, что она начинает выражать только другое измерение неискренности. Проламывание, прорывание Вивега в язык журналистов, чешских газет, бульварной прессы для этого типично. В нем Вивег дает волю своей примитивной, почти физической ненависти к некоторым политикам, даже в форме избитой песни.

Хотя автор об этом не знает или знать не хочет, он в процессе конструирования своего романа и, в особенности, своего авторского героя, очень близок к конструкциям русской классики; в некоторых статьях мы нарочно упоминали русского реалистического неоклассициста, царского цензора Ивана Гончарова с его консерватизмом и, одновременно, поисками новых путей молодых русских.

Повседневность, обыкновенность, известные из Гоголя и Гончарова, являются и доминантной темой Вивега. Между тем как оба русских писателя обнаруживают скрытый и чувствительно опустошающий фон банальности и приходят к жалостной ностальгии, Вивег реализует образ повседневности до крайнего предела: его человек подавляет, душит обыкновенные человеческие реакции, сопротивляясь шоку и неожиданности и стараясь исключить постмодернистскую неуверенность, распространяя ее на все, и, таким образом, ослабевает и ликвидирует ее. Наиболее успешно можно уничтожить то, что увеличивается, труп лучше всего скрыть в куче трупов.

Вивег конструирует своего нового человека как начитанного зверя, который воспринимает все как смерть; у него нет прочных оценочных критериев и иерархий, он культивирует свое поведение так, чтобы из жизни устранить именно неуверенность и напряжение: все предвидимо, предсказуемо, повторяемо, конфекционно, разительность можно элиминировать путем автоматизации. Рядом с демонизмом, который насильственно моделирует мир, и пассивным протеканием Вивег находит «третий путь» (tertium datur): способность отождествляться с текущим мгновеньем, с годиецентризмом нового времени.

На поверхности романы, маленькие романы, повести и рассказы Михала Вивега представляют собой постмодернистскую прозу: они амбивалентны, неуверенны, тривиальны, банальны, относятся к слою массового чтения, основаны на детективных мотивах. Но между тем как 
у постмодернистов за этими кулисами находятся и вдумчивость, созерцательность, чувство безнадежности, ностальгии и искоренения, у Вивега и эти черты постмодернизма пародированы: его «новый человек» образует и новую общественную мораль; следует жить с возможностями, которыми человек как биосоциальный объект обладает. Герои немецко-чешского бидермейера выживают так, что они были замкнуты в своем мещанском интерьере и проблемы „большого мира“ процеживали через стены своих городских квартир и принятых стереотипов; герой Вивега знает, что устоять значит подавить естественные человеческие свойства, направить свое эго в «позволенное» пространство, пользоваться каждым мгновеньем в целях выполнения актуальных представлений; в его родословной присутствует многое из персонажей уже упомянутого раннего Милана Кундеры или Владимира Парала, чешских писателей, начало творчества которых связано с 6о-ыми гг. ХХ века. «Новый человек» Вивега очевидно отказывается от большой напряженности, больших чувств и конфликтов; он убежден, что в глобализированном мире человек похож на рыбок в квартирном аквариуме, в котором все просвечено, перлюстрировано, обнажено, голо, и никто не знает, кто за кем следит: всеобщее преследование как признак, примета времени, парадоксально декларирующего охрану персональных данных и неприкосновенность индивидуума, значит, что преследование теряет смысл.

Главной проблемой героев романов и рассказов Михала Вивега является тотальная транспарентность человеческой жизни и ее публичного представления: между тем как герои литературы XIX века трагически сталкивались с обществом и дошли до тотального разочарования, литература модернизма основала свое существование на контролируемости человека и мира, постмодернизм исходил из аксиологического плюрализма, сосуществования и протекания миров и дискурсов, которые не пересекаются, а взаимно толерируют свое несходство, в квазипостмодернизме Михала Вивега индивидуум лишь растворяется в глобализированном мире, в котором он движется как астронавт в состоянии невесомости. Нецельность и метаформа мира акцентированы умножаемыми нарративными техниками, обрамлением и слоями метатекстуальности.

Все-таки тяготение к идеалу скрытно, подспудно мелькает и в квазипостмодернизме Михала Вивега, напоминающем, как выше 
сказано, неоклассицизм Ивана Гончарова, в чем не меняют ничего существенного и новые исследования конца прошлого века, связанные с фрейдизмом и юнгианством. ${ }^{12}$ И Гончаров воспринимал романтизм как детскую болезнь, от которой нормальный человек вылечится и станет рациональным пользователем спокойной, несложной жизни, живет и, по крайней мере, убежден, что он живет в кайф, в бидермейере конца XX и начала XXI веков.

Трагическое событие в жизни Вивега (разрыв аорты) в 2012 г., после которого он страдал меланхолией и провалами памяти, изменило и характер его творчества, но, как будет продемонстрировано, не полностью. Однако, он пытался конструировать другого героя (сборник рассказов Возвращение в игру). ${ }^{13}$

Этот новый путь автора труден. Автоматизм его приемов за годы творчества стал бесплодным, непрестанные повторы свидетельствуют о кризисе. Но именно этот сборник рассказов наглядно показывает конструирование нового типа творчества и, таким образом, сдвигов в подобии его героя. Больше сдержанности, самоиронии, отступления от действия, все напоминает еще сильнее раннего Кундеру из его Смешнъц любовей. В особенности фальш, фальшивые тона - это своеобразная черта вивеговских произведений, от которой автор избавляется лишь постепенно, неторопливо. В настоящем сборнике рассказов это не целиком «новый» Вивег и «новый» герой, хотя тут уже наблюдается постепенный, медленный сдвиг к заново формированному главному герою, который будто пережил свою смерть и смотрит на жизнь и мир по-другому. Это своего рода новый глоток воздуха, новый, скорее потаенный вдох, пока кризисный.

Роман Био-муж14 следует после прозаических произведений Моя жизнь после жизни (2013) и упомянутого Возвращения в игру (2015). Это особое продолжение его докризисной книги Био-жена (2010), которая была своего рода критикой супружества и его тогдашней жены; теперь автор возвращается к самокритике и конструированию нового человека, более скромного, как в предыдущих рассказах.

\footnotetext{
${ }^{12}$ Cм. M. Ehre, Oblomov and His Creator: The Life and Art of Ivan Goncharov, Princeton 1973; В.И. Мельник, Реализм И.А. Гончарова, Владивосток 1985; Р. Thiergen (ed.), I.A. Gončarov. Beiträge zu Werk und Wirkung, Köln - Wien 1989; G. Diment, The Autobiographical Novel of Co-Consciousness: Goncharov, Woolf, and Joyce, Gainesville 1994; А. Молнар, Поэтика романов И.А. Гончарова, Москва 2004. ${ }_{13}$ M. Viewegh, Zpátky ve hře, Brno 2015.

14 M. Viewegh, Biomanžel. Volné pokračování románu Biomanželka, Brno 2015.
} 
Это реализуется путем особого нарратива, нарративного метода, искусственно, шокирующим образом, в данном случае посредством женского рассказчика:

Jsem stařena. La Loba. Nejsem královna, kouzelnice, ani amazonka; jsem dula (starořecky speciálně připravená žena, která poskytuje oporu rodičce a její rodině - ip). Tančím se životem i smrtí. Jsem žena, která odhodila lodičky a nyní běhá s vlky. Poběžte se mnou, sestry moje, vezmu vás zpět na duševní území, která nám kdysi patřila ${ }^{15}$.

Именно это угол зрения, своего рода остраненный, представляет во всем романе наиболее удивительный поразительный момент. Раскаяние великого грешника, то, что Вивег критикует как гедонизм, является наиболее выразительным тематическим пластом романа. Его новый герой посыпает голову пеплом за сексуальный примискуитет, надменное торжество по случаю его пятидесятилетия, при котором растрачивались тысячи крон и т. д., все это чередуется со сценами из больницы. Все напоминает ветхозаветного Иова - почему именно я? Тема, восходящая к древнему веку, о котором писала моя бывшая докторантка в своей монографии ${ }^{16}$, возобновляется у героя Вивега: не только раскаяние, но и поиск новой подруги, изменение в био-мужа как контраст био-жены. Однако много шуму из ничего: герой Вивега - это история человека, который жил высокомерно, надменно, горделиво, потом что-то случилось и он раскаивался; раньше он считал себя центром мира, сейчас он ведет себя намного скромнее, думает о Боге, о добре и зле, замечает изменения в своем сознании и подсознании. Результатом модификаций героя мог стать брутальный поток сознания и подсознания (stream of consciousness), или что-то абсурдное, или желание оставить мир его течению, лишь смотреть на его протекание, но автор, несмотря на внешние события, остался верным своему методу письма, возвращается, хотя с оговоркой, к своим прежним, ироническим и самоироническим, травестийным приемам. Его творчество и конструирование главного героя, следовательно, образует с самого начала и в день после («day after»), одно целое, один континуум, с хорошим и плохим, добрым и злым, со словесными

\footnotetext{
${ }_{15}$ M. Viewegh, Biomanžel. Volné pokračování románu Biomanželka, Brno 2015, c. 7.

${ }^{16}$ E. Niklesová, Dialogy zoufalců: poetika a struktury. Dialogické texty o smyslu lidské existence $v$ nejstarších světových literaturách a v literaturách středoevropského areálu, Brno 2016.
} 
излияниями и зернышками блистающей красоты мира сего, но и с искусственными поэтическими рамками, которые торчат из композиции и с надменной рассказчицей, которая медленно забывает о методе остранения. Вивег пародирует, травестирует Вивега, потом к нему в своих героях возвращается, будто бы ко временам своей спасительной молодости, 90-м гг. прошлого века. И в конце опять нарциссический образ героя-автора, который стремится написать роман, осколок метатекста.

Сборник рассказов Бог в «рено»17 представляет собой ци кл, напоминающий известную серию Джона Апдайка о кролике, но в нем отсутствует новая „энергия заблуждения“, т. е. известный шаг в сторону, к заново открытым окнам, ведущим к новой литературе. Повторяется и главный герой, возвраты к метатекстуальности или же то, что главный персонаж Оскар унаследовал от предыдущих вивеговских героев - чувствительность к современности, актуальности, к текущим событиям, к политике, тяготение к своеобразным притчам и страх перед старостью и концом.

В романе Мужчина и женщина ${ }^{18}$ автор образует героя нового, нервного, полного беспокойства и неуверенности, который со страхом смотрит на мир, который ему больше не принадлежит, в котором он не чувствует себя как дома, который скорее угрожает ему, в котором все ужасно. Еще в сборнике рассказов Бог в «рено» рассказ Умение выключить, в котором описывается, как у писателя-героя, всегда портфель на правом боку и в нем все документы, деньги и кредитки, чтобы его не обокрали. С портфелем человеку приходится срастаться это фобия, которая является не столько болезнью индивидуума, сколько нашего дегенеративного века всеобщего распада структур. Вивег еще в этом сборнике осуществил свой писательский рестарт, но отчетливо обозначил и свое поле работы: скорее рассказы, здоровый эгоцентризм, чувство детали и талант наблюдателя.

Точно так развиваются герой и героиня в романе Мужчина и женцина. Автор культивирует жанр киноромана или же киноповести, ядром которых становится, как и прежде, метатекст - пререкание относительно авторской финансовой позиции. В одной рецензии я упомянул работу Вивега в качестве фельетониста в газете Lidové noviny

${ }_{17}$ M. Viewegh, Bůh v renaultu, Brno 2017.

${ }_{18}$ M. Viewegh, Muž a žena, Praha 2018. 
- его фельетоны с литературной, эстетической точек зрения слабые, но в них содержится то, что в настоящем диптихе: зов о помощи, страх перед одиночеством и смертью. Определенная одержимость здорова; иногда он наметил и путь в другую сторону, и новое развитие сюжета.

Темы отдельных рассказов подтверждают тяготение автора и его персонажей к определенному подниманию, бегству из тупика, поискам новых позиций. Рассказы Вивега частично напоминают - в связи с упомянутой Книгой Иов - отчаянного неудачника, стоящего лицом к лицу с неумолимым миром, в котором нельзя нормально жить, несмотря на все попытки выхода и поиска света в тоннеле. Рассказы также касаются жизненного краха, неизбежной старости и конца.

Большим возвращением молодости к Вивегу, хотя скорее затяжной, протрагированной, является пока его последний роман 2020 года Преимущественно вежливый Леопольд. ${ }^{19}$ Каждому критику автор может быть симпатичен тем, что именно критиков своих произведений он полностью игнорирует и, в основном, пренебрегает ими, что, парадоксально, может открыть им рот или клавиатуру компьютера, именно потому, что настоящая литературная критика в некоторых государствах - кроме ненавистных излияний или низкопоклонства друзьям или даже идеологической поддержки - сегодня не существует. Вивег постоянно тяготеет к киносценариям и их медиализации. В настоящем романе присутствует драматизация в форме диалога в романе, в котором приводятся имена действующих лиц.

Писатель в романе о Леопольде решает не политику, проблемы мужчин и женщин, мужей и жен, половой промискуитет, но, прежде всего, неудержимое старение и постоянную поддержку постепенно гаснущей сексуальности. Леопольд как главный герой отличается от своих предшественников тем, что он - несмотря на продолжающиеся словесные излияния - сохраняет определенную долю обязательной вежливости. Его половые связи состредоточиваются лишь на близких людях - это жена, молодая вдова и еще одна женщина, между которыми он бьется. Они едут на так называемый Сазавафест, традиционный музыкальный фестиваль. Все три женщины обманут его, и он очутится в кабинете психиатра. Историкам литературы в этом случае посчастливилось, так как можно легко реконструировать время и место действия, так как Сазавафест в городе Светла-на-Сазаве состоялся

19 M. Viewegh, Převážně zdvořilý Leopold, Praha 2020. 
25-27 июля 2019 г., т. е. накануне закрытия? = приостановления жизни. Как известно, римляне не остановили свои вакханалии и накануне 476 г. нашей эры. Роман является, следовательно, хотя почти случайно, концом одной эпохи, концом попыток автора перезагрузить свое писательское ремесло и концом исторической эпохи, цивилизации и культуры, как они выглядели раньше. В этом смысле конфронтации героев и героинь вивеговских романов - это оригинальная запись, своего рода документ истории человека конца XX и начала XXI веков, когда он стал свидетелем переломных, роковых событий, хотя он почти ничего не заметил, и движется в известном русле гедонизма и годиецентризма. Автор - под воздействием серьезного заболевания почти изменил своего героя, сам пытаясь стать иным - он и его герои но попытка не увенчалась успехом. Он застрял на полпути и потом вернулся к старому образу героя, однако без прежней энергии.

Романы и рассказы Вивега - это анатомия и физиология человека Центральной Европы, которая по своему всегда стремилась к поискам новых путей, к началу новых эпох, к антиципации, предвосхищению новых идей и к формированию новых людей в измененных условиях. Его человек - типичный центральноевропеец - homo Europae centralis - как и его предшественники в выше упомянутых произведениях других авторов, которые старались сохранить свои центральноевропейские признаки, приметы и назначение. Хотя это не столь выразительно, как у его предшественников, Вивег - уже по своей квазипостмодернистской поэтике, по своим крайним взглядам и языковым и стилевым изобретениям относится, пусть скрыто или откровенно, к могучему потоку неясной, туманной, амбивалентной центральноевропейской литературы, которая в кризисный момент опять дает о себе знать.

\section{Литература}

Diment G., The Autobiographical Novel of Co-Consciousness: Goncharov, Woolf, and Joyce, Gainesville 1994.

Ehre M., Oblomov and His Creator: The Life and Art of Ivan Goncharov, Princeton 1973.

Мельник В.И., Реализм И.А. Гончарова, Владивосток 1985.

Молнар А., Поэтика романов И.А. Гончарова, Москва 2004. 
Niklesová E., Dialogy zoufalců: poetika a struktury. Dialogické texty o smyslu lidské existence $v$ nejstarších světových literaturách a $v$ literaturách středoevropského areálu, Brno 2016.

Pospísil I., Central Europe: Substance and Concepts, Nitra 2015.

Pospíšil I., Методология и теория литературоведческой славистики и Центральная Европа, Siedlce 2015.

Pospísil I., Český kvázipostmoderní román: poetizace automatismu a zrození „nového člověka“ (Př́pad nevěrné Kláry Michala Viewegha), [в:] Retoriki na pametta. Jubileen sbornik $v$ čest na 6o-godišninata na profesor Ivan Pavlov, ред. B. Biolčev, V. Stefanov, K. Bachneva, P. Karagjozov, J. Bačvarov, Sofija 2005, c. 498-504.

Pospíšil I., El centrismo interliterario mediterráneo y la literatura russa, [в:] Literatura europea comparada, compilación de textos C. Domínguez, Madrid 2013, c. 313-322.

Pospísil I., Humor jako mobilizace psychiky, potencialita, zmarňování, přesah a nebezpečí (Sedmý životopis Oty Filipa a jeho předchůdci), „Stylistyka” 2001, $\mathrm{nr}$ X, c. 33-46.

Pospísil I., Il centrismo interletterario mediterraneo e la letteratura russa, [в:] Il Mediterraneo. Una rete interletteraria. La Méditerranée. Un réseau interlittéraire. Stredomorie - medziliterárna siet', a cura di D. Ďurišin, A. Gnisci, Roma 2000, c. 101-109.

Pospíšil I., Karel Krejčí, jeden sborník a úloha tzv. fyziologiú, [в:] Karel Krejčí a evropské myšlení, eds. I. Pospíšil, M. Zelenka, Brno 2006, c. 39-47.

Pospíšil I., Lekce tữrč́ho psaní a kvázipostmodernistická poetika Michala Viewegha, „Stil“ 2005, nr 4, c. 303-313.

Pospíšil I., Literatura a úzkost: Ota Filip a Oksana Zabužko, „Bohemica Litteraria” 2001, V. 4, c. 147-153.

Pospíšil I., Mitteleuropäische Dimension und mitteleuropäisches Schicksal in Ota Filips konfessionelem Roman-Dokument Sedmý životopis, [в:] Litteraria Humanitas XI. Crossroads of Cultures: Central Europe, ed. I. Pospíšil, Brno 2002, c. 305-316.

Pospíšil I., Osobnost a literární žánr v kleštích dějin (Poetika dějinného zmarňování na pomezí faktu a fikce aneb Ahasver 20. století: román Oty Filipa Sedmý životopis, „Slavia Occidentalis” 2001, t. 58, c. 58-155.

Pospísil I., Postmodernism and Quasipostmodernism (Michal Viewegh), „Neohelicon. Acta Comparationis Litterarum Universarum. Akadémiai Kiadó" 2006, tomus XXXIII, fasciculus 2, Decemnber, c. 37-44.

Pospíšil I., Problémy terminologie a střední Evropa, [в:] Brněnská hungaroslavistika a česko-slovensko-mad’arské vztahy, eds. I. Käfer, I. Pospísil, E. Sztakovicsová. Szeged 2012, c. 45-57.

Pospísil I., Quasipostmodernistyczny świat Michala Viewegha, [в:] Literatury stowiańskie po roku 1989. Nowe zjawiska, tendencje, perspektywy, Tom I, Transformacja, red. H. Janaszek-Ivaničkova, Warszawa 2005, c. 81-88.

Pospísil I., Střední Evropa a Slované (Problémy a osobnosti), Brno 2006. 
Pospísil I., Střední Evropa: posuny důrazu, [v:] Střední Evropa včera a dnes: proměny koncepcí. Kolektivní monografie, ed. I. Pospíšil, Brno 2015, c. 9-20.

Pospísil I., Vizualizace v komplexu uměleckých detailů v románu Oty Filipa Sedmý životopis, [в:] Dwudziestowieczna ikonosfera w literaturach europejskich. Wizualizacja $w$ literaturze, red. B. Tokarz, Katowice 2002, c. 299-307.

Pospíšil I., Zelenka, M., René Wellek and Interwar Czechoslovakia: the Roots of Structural Aesthetics. BUNMEI (Civilisation) 17, Tokyo 1998, c. 79-89.

Pospíšil I., Zelenka, M., Střední Evropa jako křižovatka metodologií: Slovesnost Slovanů Franka Wollmana - tradice a souvislosti (Nad druhým českým vydáním), [in:] F. Wollman, Slovesnost Slovanů, eds. I. Pospíšil, M. Zelenka, Brno 2012, c. 23-68.

Pospísil I., Ареальные исследования: между Центральной Европой и Россией, [в:] Kultura rosyjska $w$ ojczyźnie $i$ diasporze. Księga jubileuszowa dedykowana profesorowi Lucjanowi Suchankowi, red. L. Liburska, Kraków 2007, c. 49-57.

Pospísil I., Проблематика сущности и развития русской литературы с точки зрения Цетральной Европы, [в:] W kręgu języka, literatury i nauczania, ред. Л. Павера, Bielsko-Biała 2017, c. 215-232

Pospísil I., Рождение среднеевропейской поэтики (Ф. Каутман - О Филип Й. Зогата - М. Вивег), [в:] Взаимодействие литератур в мировом литературном процессе. Проблемы теоретической и исторической поэтики. Материалы Х международной научной конференции в двух частях. часть 1, ред. Т.Е. Автухович, Гродно 2005, с. 79-91.

Pospísil I., Россия и Центральная Европа с особым учетом чешско-русских литературных связей, [в:] Универсалии русской литературы 2, сборник статей, ред. А.А. Фаустов, Воронеж 2010, с. 606-628.

Pospísil I., Средняя Европа как перекресток литературоведческой методологии, [в:] Взаимодействие литератур в мировом литературном процессе (Проблемы теоретической и исторической поэтики). Материалы международной научной конференции, часть 1, отв. ред. Т.Е. Автухович, Гродно 1997, с. 3-10.

Thiergen P. (ed.), I. A. Gončarov. Beiträge zu Werk und Wirkung, Köln - Wien 1989.

Viewegh M., Lekce tvưrčího psaní, Brno 2005.

Viewegh M., Biomanžel. Volné pokračování románu Biomanželka, Brno 2015.

Viewegh M., Převážně zdvořilý Leopold, Praha 2020.

Viewegh M., Bůh v renaultu, Brno 2017.

Viewegh M., Muž a žena, Praha 2018.

Viewegh M., Př́pad nevěrné Kláry, Brno 2003, c. 49-50.

Viewegh M., Zpátky ve hře, Brno 2015. 


\section{References}

Diment G., The Autobiographical Novel of Co-Consciousness: Goncharov, Woolf, and Joyce, Gainesville 1994.

Ehre M., Oblomov and His Creator: The Life and Art of Ivan Goncharov, Princeton 1973.

Mel'nik W.I., Riealizm I. A. Gonczarowa, Vadivostok 1985.

Molnar A., Poetika romanow I. A. Gonczarowa, Moskva 2004.

Niklesová E., Dialogy zoufalců: poetika a struktury. Dialogické texty o smyslu lidské existence $v$ nejstarších světových literaturách $a v$ literaturách středoevropského areálu, Brno 2016.

Pospíšil I., Roždenie sredneevropejskoj poètiki (F.Kautman - O Filip - J.Zogata M. Viveg), [w:] Vzaimodejstvie literatur $v$ mirovom literaturnom processe. Problemy teoretičeskoj i istoričeskoj poètiki. Wzaimodiejstwije litieratur $w$ mirowom litieraturnom processie. Problemy tieorieticzeskoj i istoriczeskoj poetiki. Materialy X meždunarodnoj naučnoj konferencii $v$ dvuh častâh, čast' 1, red. T.E. Avtuhovič, Grodno 2005, s. 79-91.

Pospísil I., Areal'nye issledovaniâ: meždu Central'noj Evropoj i Rossiej, [w:] Kultura rosyjska $w$ ojczyźnie i diasporze. Księga jubileuszowa dedykowana profesorowi Lucjanowi Suchankowi, red. L. Liburska, Kraków 2007, s. 49-57.

Pospísil I., Central Europe: Substance and Concepts, Nitra 2015.

Pospíšil I., Český kvázipostmoderní román: poetizace automatismu a zrození „nového člověka“ (Př́pad nevěrné Kláry Michala Viewegha), [в:] Retoriki na pametta. Jubileen sbornik $v$ čest na 6o-godišninata na profesor Ivan Pavlov, ред. В. Biolčev, V. Stefanov, K. Bachneva, P. Karagjozov, J. Bačvarov. Sofija 2005, c. 498-504.

Pospíśil I., El centrismo interliterario mediterráneo y la literatura russa, [в:] Literatura europea comparada, compilación de textos C. Domínguez, Madrid 2013, c. 313-322.

Pospíšil I., Humor jako mobilizace psychiky, potencialita, zmarňování, přesah a nebezpečí (Sedmý životopis Oty Filipa a jeho předchůdci), „Stylistyka” 2001, nr X, c. 33-46.

Pospíšil I., Il centrismo interletterario mediterraneo e la letteratura russa, [в:] Il Mediterraneo. Una rete interletteraria. La Méditerranée. Un réseau interlittéraire. Stredomorie - medziliterárna siet', a cura di D. Ďurišin, A. Gnisci, Roma 2000, c. 101-109.

Pospíšil I., Karel Krejčí, jeden sborník a úloha tzv. fyziologiú, [в:] Karel Krejčí a evropské myšlení, eds. I. Pospíšil, M. Zelenka, Brno 2006, c. 39-47.

Pospísil I., Lekce tvưrčího psaní a kvázipostmodernistická poetika Michala Viewegha, „Stil“ 2005, $\mathrm{nr} 4$, c. 303-313.

Pospíšil I., Literatura a úzkost: Ota Filip a Oksana Zabužko, „Bohemica Litteraria” 2001, V 4, c. 147-153. 
Pospíšil I., Metodologiâ i teoriâ literaturovedčeskoj slavistiki i Central'naâ Evropa, Siedlce 2015.

Pospíšil I., Mitteleuropäische Dimension und mitteleuropäisches Schicksal in Ota Filips konfessionelem Roman-Dokument Sedmý životopis, [в:] Litteraria Humanitas XI. Crossroads of Cultures: Central Europe, ed. I. Pospíšil, Brno 2002, c. 305-316.

Pospíšil I., Osobnost a literární žánr v kleštích dějin (Poetika dějinného zmarňování na pomezi faktu a fikce aneb Ahasver 20. století: román Oty Filipa Sedmý životopis, „Slavia Occidentalis” 2001, tom 58 (2001), c. 58-155.

Pospísil I., Postmodernism and Quasipostmodernism (Michal Viewegh), „Neohelicon. Acta Comparationis Litterarum Universarum. Akadémiai Kiadó" 2006, tomus XXXIII, fasciculus 2, Decemnber, c. 37-44.

Pospísil I., Problematika suŝnosti i razvitiâ russkoj literatury s točki zreniâ Cetral'noj Evropy, [в:] $W$ kręgu języka, literatury i nauczania, red. L. Pawera, Bielsko-Biała 2017, c. 215-232

Pospíšil I., Problémy terminologie a střední Evropa, [в:] Brněnská hungaroslavistika a česko-slovensko-mad’arské vztahy, eds. I. Käfer, I. Pospíšil, E. Sztakovicsová, Szeged 2012, c. 45-57.

Pospísil I., Quasipostmodernistyczny świat Michala Viewegha, [в:] Literatury stowiańskie po roku 1989. Nowe zjawiska, tendencje, perspektywy. Tom I. Transformacja, red. H. Janaszek-Ivaničkova, Warszawa 2005, c. 81-88.

Pospíšil I., Rossiâ $i$ Central'naâ Evropa s osobym učetomčešsko-russkih literaturnyh svâzej, [w:] Universalii russkoj literatury 2, sbornik statej, red. A.A. Faustov, Voronež 2010, s. 606-628.

Pospíšil I., Srednââ Evropa kak perekrestok literaturovedčeskoj metodologï, [v:] Vzaimodejstvie literatur $v$ mirovom literaturnom processe (Problemy teoretičeskoj $i$ istoričeskoj poètiki). Materialy meždunarodnoj naučnoj konferencii, čast' 1, otv. red. T.E. Avtuhovič, Grodno 1997, s. 3-10.

Pospíšil I., Střední Evropa a Slované (Problémy a osobnosti), Brno 2006.

Pospísil I., Střední Evropa: posuny důrazu, [v:] Střední Evropa včera a dnes: proměny koncepcí. Kolektivní monografie, ed. I. Pospíšil, Brno 2015, c. 9-20.

Pospíšil I., Vizualizace v komplexu uměleckých detailů v románu Oty Filipa Sedmý životopis, [в:] Dwudziestowieczna ikonosfera w literaturach europejskich. Wizualizacja $w$ literaturze, red. B. Tokarz, Katowice 2002, c. 299-307.

Pospíšil I., Zelenka, M., René Wellek and Interwar Czechoslovakia: the Roots of Structural Aesthetics. BUNMEI (Civilisation) 17, Tokyo 1998, c.79-89.

Pospíšil I., Zelenka, M., Střední Evropa jako křižovatka metodologií: Slovesnost Slovanů Franka Wollmana - tradice a souvislosti (Nad druhým českým vydáním), [in:] F. Wollman, Slovesnost Slovanů, eds. I. Pospíšil, M. Zelenka, Brno 2012, c. 23-68.

Thiergen P. (ed.), I.A. Gončarov. Beiträge zu Werk und Wirkung, Köln - Wien 1989. Viewegh M., Lekce tvưrčího psaní, Brno 2005.

Viewegh M., Biomanžel. Volné pokračování románu Biomanželka, Brno 2015.

Viewegh M., Bůh v renaultu, Brno 2017. 
Viewegh M., Muž a žena, Praha 2018.

Viewegh M., Převážně zdvořilý Leopold, Praha 2020.

Viewegh M., Př́pad nevěrné Kláry, Brno 2003.

Viewegh M., Zpátky ve hře, Brno 2015. 